\title{
History of Forest Enterprise Management Development in Macedonia
}

Aneta Blazevska

University of St. Kiril and Metodij, Skopje,

Faculty of Forestry,

Skopje, Macedonia

e-mail: ablazevska@gmail.com

\section{Abstract}

Background and Purpose: The central theme of the paper is the development of forest enterprise management in Macedonia and the adaptation to changes throughout the history. The change has become a permanent phenomenon that has to be addressed and managed appropriately in order to ensure organizational survival. Because of the changes in technology, the market place, social values and work force created a dynamic and unpredictable environment especially for those organizations who are unable to respond to the changes and adapt.

Methods and Methodology: For the purpose of the research, a content analysis was applied to forest enterprises that appeared in all documents starting from 1900 to 2012. In order to increase the validity of the research and avoid any gaps, the data was divided into categories according to the meaning of the words. Hence, words with similar meanings were placed into the same categories, in order to obtain a better review of the researched phenomena.

Results and Conclusions: The results showed that throughout the history there were different types of forests enterprise managements in Macedonia. According to the analysed documents, during the period of the administration after the World War II (May 1945) the first federal forest company "FESUMA" was established with the help of ASNOM (Anti-Fascist Assembly for the People's Liberation of Macedonia) and the Department of Forestry and Mining. All modifications of forests funds and legislation thereafter have influenced and provoked a lot of changes in the forest enterprise management. At the same time it is interesting to emphasize that the results obtained from the research show that in order to survive and stay competitive on the market, forest enterprises have been developing and adapting to the changes in the environment.

Keywords: forest enterprise management, modifications, development, adaptation, history, changes
Makedonka Stojanovska

University of St. Kiril and Metodij, Skopje,

Faculty of Forestry,

Skopje, Macedonia

\section{INTRODUCTION}

The following sentence is often attributed to Charles Darwin: "It is not the strongest of the species that survive, or the most intelligent, but those most responsive to change". As Darwin noticed, change has been an impelling force in the society since the beginning of mankind. Thus, the same should apply for the institutions and organizations created by man. Only the companies who are flexible enough to respond to the shifts in the market environment survive. The ones who stagnate slowly fade and vanish as the history has so expressively shown us. Although the speed of those transformations and evolutions has increased rapidly during the last decades, the phenomenon itself is not new [1].

The change has become a permanent phenomenon that has to be addressed and managed appropriately in order to ensure organizational survival, as Church and McMahan stated in 1996. They asserted that changes in technology, the market place, social values, work force demographics, and the political environment all had a significant effect on the processes, as well as on the products and services produced. The culmination of these forces reflected an external environment that was dynamic, unpredictable and often devastating to those organizations that were unprepared or unable to respond, they added [2].

While talking about organizational changes, we should start with defining what the meaning of the word organization is as the main subject of modification. In our everyday life we mainly use the word organization for an organized business activity of a group. As defined in the Thesaurus Online Dictionary, an organization is "a structure through which individuals cooperate systematically to conduct business". In the academic world various theoretical approaches set different priorities while defining the essence of organizations [1]. 
According to Hall [3], "Organizations are a dominant component of contemporary society". They surround us. We are born in them and die in them. The space between us is filled with them. They are just about impossible to escape. They are as inevitable as death and taxes. The great social transformations in history were essentially organizationally based. The Roman Empire, the spread of Christianity, the growth and development of capitalism and socialism, and the changes that took place in both capitalism and socialism were and still are accomplished through organizations. These simple examples were intended to suggest that the careful analysis of organizations is a serious and important matter [3].

Organizations need to take into consideration a multitude of different expectations. Expectations and values need to be coherent with the prospected output. Also, organizations have to take into consideration the wants and needs of the society and the ideas of this society regarding their function and the ultimate necessity. The ability of organizations to adapt and change has become a central research issue focusing on the complexities of regulatory, political, technological and social changes. Nowadays, it is commonplace to note that the volatility of changes confronting organizations has dramatically increased [4].

\section{PROBLEM STATEMENT}

The first written documents regarding forest enterprise management in Macedonia appeared at the beginning of the 1900's. In 1992, Macedonia declared independence from the former Yugoslavia and shifted from the monopolistic into a pluralistic and democratic society which caused many changes. All the changes that happened over time, did not only evoke a shift in forest areas and legislation, but at the same time provoked changes in the forest enterprise management. Taking into account that around 35\% of the surface in Macedonia is covered by forests, out of which $90 \%$ belong to and are managed by state enterprises, the forest enterprise management is of a particular importance not only to the enterprises themselves, but also to the entire forest sector of the country. Hence, the obtained data regarding the development of forest enterprise management is to provide important information for the main instigators of modifications and, on the other hand, such data will provide recommendations for the more appropriate types of forest enterprise management.

Until today, many studies have been done regarding forestry issues in Macedonia, but there is a lack of particular studies exploring the development of forest enterprise management and the adaptation to changes throughout the history. Bearing in mind the importance of the adaptation to changes for enterprises and their survival, as well as the fact that this is a completely new and unexplored component, this research emphasizes the significance and importance for the entire forest sector.

\section{OBJECTIVES OF THE RESEARCH}

In order to better understand the speed and limits of adaptations to changes in forest enterprise management, it was very important to have a clear overview of the changes over time. Hence, the problem statement of this research is to better understand the development and adaptation of the forest enterprise management in Macedonia in last 100 years. Thus, goal of the study was to achieve and broadly elaborate the following objectives:

- Identify the types of forest enterprise management over time.

- Analyze and describe the adaptation to changes of the forest enterprise management in Macedonia over time.

The purpose of this study is to explore and highlight the main characteristics of the historical development of forestry enterprises and to give a clear review on changes throughout the history regarding forests areas, legislation and forest management. In order to meet the objective of this study, the following research questions were examined:

- Which forests enterprises have been developing in forestry in Macedonia over time?

- How have forests enterprises developed and adapted to changes in Macedonia over time?

The response to those questions gave a clear overview of the development of enterprises in forestry in Macedonia and their adaptation throughout the history.

\section{THEORETICAL FRAMEWORK}

Throughout the history, many scientists attempted to analyze and explore organizations, starting from their own point of view, thereby concentrating on various aspects of organizations and applying different theories for the purpose of their own studies. Before we continue with theories that analyze organizations, it may be useful to define some common terms first. Webster's Dictionary defines an organization as "an association or a society of people working together to some end". Organization theory refers to the broad body of literature that explores the structure and design of organizations. Organization theory may be separated into sub-specialties, looking at different aspects of an organization. 
Some organization theorists observe an organization's structure, and suggest ways an organization may redesign itself for a better performance. Other organization theorists observe an organization's processes or personnel, while others explore the importance of the rewards systems to motivate employees. Organization theorists both describe how organizations operate, and suggest how they may improve to operate more effectively and efficiently [5].

For the purpose of this research and at the same time in order to better analyze and explore the development of organizations in forestry and to understand their adaptation to changes throughout the history, organizational learning theory was applied.

Organizational learning theory is consists of models about the way organizations learn and adapt to the changing environment. In order to be competitive in a changing environment, an organization has to learn and change its goals and actions in response to changes of circumstances, as well as to link their actions to the outcome.

The notion of organizational learning as a key process within an organization modulating and shaping its performance might be traced back to the beginning of the 1960-s [6]. Organizational learning was conceived as a part of the managers' portfolio, and managers have been increasingly adopting the notion, to the extent that many managers consider organizational learning to be a powerful tool to improve the performance of an organization [6]. Organizational learning is an adaptive process where goals, attention rules and search rules adapt to the experiences within the organization.

The later developments included a distinction between adaptive learning - a response to the changed environmental conditions - and proactive learning - the planned organizational changes reaching beyond the mere reaction to environmental changes. Adaptive learning is considered more automatic and less cognitively induced than proactive learning. Hence, many theorists consider adaptive learning inferior to proactive learning [7]. Some authors emphasized that organizational decisions depended on certain rules and, hence, that organizational learning was executed on the basis of rules. The rules were determined and (re)shaped by experiences gained within this organization [5].

According to Senge [8], learning organizations are: "Organizations where people continually expand their capacity to create the results they truly desire, where new and expansive patterns of thinking are nurtured, where collective aspiration is set free, and where people are continually learning to see the whole together".

In the situation of a changing environment only those who are flexible, adaptive and productive seem to be able to stand out. Thus, organizations have to consider how to challenge people to commit and learn at all levels. Senge [8] identified five disciplines of organizational learning: system thinking, personal mastery, mental models, building shared vision and team learning. System thinking means the interaction with other components in the system, that is, instead of isolating things as a single unit, they are observed as a range of interactions within the whole system. If I believe that my current state was created by somebody else, or by forces outside my control, why should I hold a vision? The central premise behind holding a vision is that somehow I am able to shape my future; System thinking helps us understand how our own actions shape our current reality, thereby giving us confidence that we may create a different reality in the future [9].

Personal mastery is: "The discipline of personal growth and learning" [8]. "Organizations learn only through individuals who learn. Individual learning does not guarantee organizational learning. But without it no organizational learning occurs". "People with a high level of personal mastery live in a continual learning mode. They never 'arrive'. Sometimes, language, such as the term 'personal mastery' creates a misleading sense of definiteness, of black and white. But personal mastery is not something you possess. It is a process. It is a lifelong discipline. People with a high level of personal mastery are acutely aware of their ignorance, their incompetence and their growth areas. And they are deeply self-confident. Paradoxical? Only for those who do not see the 'journey is the reward" [8]. People with a high level of personal mastery have the ability to create personal visions and accurately assess their reality according to their vision. In order for an organization to become successful in learning, it should include people at all levels capable of personal mastery, but who understand that personal mastery is a choice and not an order. Thus, organizations should create an environment that may assist employees to developed personal mastery [5].

In the words of Hall [8]: "Mental models are deeply held internal images of how the world works, images that limit us to familiar ways of thinking and acting. Very often, we are not consciously aware of our mental models or the effects they have on our behavior". 
In the learning process every organization has to develop its own capacity for people to change their mental models and learn new skills, because metal models have to be changed first in order to be able to change the future. A shared vision is a driving force for an improvement and a base for engagement and trust in the company [8]. The main idea of a shared vision is the common dream or goal of the individuals in an organization, this idea inspires work to achieve the vision [8] and considers the team a key-learning unit in the organization. Hall [8] defined team learning as "the process of aligning and developing the capacity of a team to create the results its members truly desire. It builds on the personal mastery, for talented teams are made up of talented individuals".

There are three dimensions of team learning: the first dimension is to think insightfully about complex issues, the second is the ability to take innovative and coordinate actions and the last one is the ability to create a network that will allow other teams to take action as well.

\section{METHODOLOGY}

The research design of this study has a descriptive character; therefore it uses the content analysis of relevant documents as a research method for the purpose of the study.

Content analysis is a method of analysing written, verbal or visual communication messages. Content analysis as a research method is a systematic and objective means of describing and quantifying phenomena. It is also known as a method of analysing documents. Content analysis allows the researcher to test theoretical issues to enhance the understanding of the data. Through a content analysis, it is possible to distil words into fewer content-related categories. It is assumed that, when classified into the same categories, words, phrases and the like share the same meaning [10].

The research was conducted in Skopje during 2012 and the areas of research were forest enterprises appearing in all documents, starting from the early 1900 until 2012. A content analysis was done on the following written documents: previous research of others that are in some way more or less related to the subject of this research, dissertations, reports from the public enterprise, forest laws, strategies, trade laws, laws on public supply, scientific articles, internet sources, as well as all other relevant literature that enabled a clear overview of the development and adaptation to the changes in forest enterprise management. To get a better overview, as well as to increase the validity of data and skip potential mistakes during research, data was divided into three categories forest area, legislation and management. Hence, the words of similar meaning were placed into the same categories, in order to enable a better and clear review of the research phenomena. At the same time it was very important to highlight that the approach of the content analysis of this research was deductive, taking into account that a theory was tested during the research, which means a move from the general to the specific.

\section{RESULTS}

In order to understand the history of the development of forests enterprise management in Macedonia more clearly, the obtained results were divided into three parts. The first part was related to forest funds, the second to forest legislation and the third part to forest enterprise management. The aim of exploring forest funds and legislation was to gain a better insight and understanding of the relations to the changes in forests enterprise management. At the same time that helped point out the main instigators which provoked changes in forests enterprises over the years. The analysis performed on relevant strategies, documents, dissertation, articles, laws and other relevant documents, for the purpose of this study, obtained the following results.

\section{Forest areas}

According to the statistical data on Macedonian forests in 1938, there were about 615216 ha of forests or about $24 \%$ of the total geographical area. Of all the forests at that time, 162054 ha or $26.3 \%$ were state-owned, 360797 ha or $58.6 \%$ were rural or communal, 84914 or $13.8 \%$ were private and 7496 ha or $1.2 \%$ were church forests. The statistical data from 1938 was used for the period of the Second World War. In the period from 1947-1949 the socalled "first inventory" was done at the level of the former SFR Yugoslavia [11].

The first forest inventory was carried out in 1961 and according to it, the total forest area was about 887517 ha from the total geographical area of the Republic of Macedonia where the surface of land without the forest cover was 411398 ha. This means that the total forest surface and areas without the forest cover were 1298915 ha or about $50.5 \%$ of the geographical area. Of the total forest area, 792025 ha or $89.3 \%$ were commercial forests, 52486 ha or $5.9 \%$ were protected and 42006 ha or $4.7 \%$ special purpose forests. The second inventory of forests was carried out in 1979. According to the obtained data from the second forest inventory 
TABLE 1

Forest areas in Macedonia

\begin{tabular}{|c|c|c|c|}
\hline Year & Total forest area (ha) & Type of forest & Forest area (ha) \\
\hline \multirow{4}{*}{1938} & \multirow{4}{*}{615216} & state & 162054 \\
\hline & & rural & 360797 \\
\hline & & private & 84914 \\
\hline & & church & 7496 \\
\hline \multirow{3}{*}{1961} & \multirow{3}{*}{887517} & commercial & 792025 \\
\hline & & protected & 52486 \\
\hline & & special & 42006 \\
\hline \multirow{2}{*}{1979} & \multirow{2}{*}{905653} & state & 816633 \\
\hline & & private & 89020 \\
\hline
\end{tabular}

in 1979, the total forest area in Macedonia was 905653 ha or about $35.2 \%$ of the total surface of the Republic of Macedonia. In 1961 forest area was increased by about 18136 ha or $2.0 \%$. From the data we may conclude that forest funds from 1961 to 1979 , from first to the second inventory, changed significantly in their manufacturing capability and less in the amount of forest area. Such changes were the result of many cultivation measures, as well as the continuous and comprehensive preventive care of forests [11].

The total forest area was 950594 ha in 1999 which, compared to the forest area in 1979, meant an increase of 60288 ha or about $5.0 \%$. The state-owned forest areas increased from 816633 ha in 1979 by 838599 ha or for about $2.7 \%$, while privately-owned increased from 89020 ha to 11995 ha or more than 25.8\% [12].

\section{Forest Legislation}

Forest management is regulated and determined by forest laws. Historically speaking, forest legislation in Macedonia is recent. The first forest law was adopted before the Second World War, in 1929, by the Kingdom of the Serbs, Croatians and Slovenians or Yugoslavia, a part of which the Republic of Macedonia was at that time. This law with some amendments was in force until the Second World War. After the Second World War, in 1947, a General Forest Law was passed, while Forests Statutes were passed in 1961 and 1965. In 1997 the new Forest Law in Macedonia was adopted (The Official Gazette of R.M, No.47/97).

Forests and forest lands are legally treated in societies as the natural wealth and therefore special protective measures are provided by the law. Their cultivation, utilization and protection has to be performed in a manner to preserve their value, increase the growth and yield under natural conditions, as well as to preserve and improve their production and useful functions [11].

\section{Forest Enterprise Management}

1965, when the Secretariat of Forestry at the Executive Council of NRM was formed. In the middle of 1968 , the Secretariat of Forestry transformed into the Secretariat of Agriculture and Forestry of NRM. At that time, the Directorate for Wood Industry established several self-managed wood industry companies, while forest entities operated as self-financing institutions [11].

Forest entities and national parks were established by the National Board for the Environment. In 1957, twenty four forests entities were established in Macedonia , two national parks, two administrations for urban and non-urban greenery and seven sections for rain torrent regulations. In the period from 1960 until 1970, certain integration processes occurred not only between forests entities that turned into economic organization, but also occurred between forestry and wood industry. At that time two industry organizations in Macedonia: "Treska Skopje" and "Macedonia wood" were founded. After the constitutional changes in 1974 and the adoption of the Law on Associated Labour, or popularly called the Workers' Constitution, in 1976, the economic entities formerly working as companies, organizations and institutions, etc., were organized as Organizations of Associated Labour (OUR), or the Basic Organizations of Associated Labour (OOUR), respectively. The notion of those basic organizations generally, and in the forestry in particular, meant basic organizations, working organizations, complex organizations and other higher forms of association. Namely, the Basic Organizations of Associated Labour (OOUR) merged into Working Organizations (RO), and those into Complex Organizations of Associated Labour (SOUR). At the end of 1980, some changes occurred in the organization of 
economic entities, changes based on the constitutional amendments passed in 1988, when the Trade Law was adopted (The Official Gazette of the Socialist Federal Republic of Yugoslavia, No. 77/88) when the current law on associated labour was practically suspended. In the next 2-3 years, disintegration processes occurred in forestry, so most of the forests entities that operated as OOURs in the framework of Working Organizations (RO) or independently until then, were organized as Communal Organizations for the Management of Forests. Hence, until the adoption of the new law on forests in 1997 (The Official Gazette of R. of Macedonia, No.47/97), out of the thirty 30 (thirty) former forests entities, 28 (twenty eight) were organized as communal organization, while Kruševo and Delčevo were organized as public enterprises. Based on Article 17 of the Forest Law (The Official Gazette of R. of Macedonia, No. 47/97) and Article 46, paragraph 3 of the Administrative Law of the Republic of Macedonia (The Official Gazette of the Socialist R. of Macedonia, No. 38/90 and The Official Gazette of R. of Macedonia, No. 63/94), the Government of Macedonia decided to establish a public enterprise for forest management (The Official Gazette of R. of Macedonia, No.65/97) on their meeting held on December 15,1997 [11].

The public enterprise for managing forests "Macedonian Forests" has been managing public forests in the Republic of Macedonia. The enterprise was founded on July 1, 1998 as the legal successor of several forests economic entities that had been managing forests until then. For the successful and efficient performance of its activities, the public enterprise "Macedonian Forests" was organized into one head office and thirty branch offices, with the centralized budget and decision-making system.

For the efficient and rational management, forests were divided into commercial forest units. The management of private and state-owned forest, regardless their purpose, is now in accordance with the general management plans adopted by the Government of the Republic of Macedonia for the period of twenty years. The general management plan determines the management of forests in accordance with natural conditions and opportunities for existence, regeneration and development of forests, also dividing forests by type, preservation, timber, road infrastructure, vulnerability to negative influences, general directions and goals for future management measures for the care, protection, development, improvement and expansion of forests in the Republic of Macedonia. In accordance with the general management plans, the public enterprise has adopted special plans for forest management for the duration of ten years. Action or special plans were later approved by the Ministry of Agriculture, Forest and Water Management, while the control of the performed activities from action plans is done by the Forest Inspectorate. Considering the fact that one of the most important actions in forestry is forest management. Particularly because of the forests' multifunctionalities, the management of forests is organized through the public enterprise. Beside the public enterprise, that was mainly established to perform activities of public interest, it is possible to establish other forms of organizations in forestry regulated by special laws on trade companies. By adopting the Trade Law, old terminology also changed, and this Law also meant the expiration of the old legislation on companies (The Official Gazette of R.M., No. 15/93) where the term "enterprise" was used as a synonym for a profitable economic entity. Thus all legal subject that performed activities of public interest and that were founded as Public Enterprises, are now organized as trade companies respectively, according to the Trade Law on Companies [11].

\section{DISCUSSION AND CONCLUSIONS}

The relationship between the development and adaptation of forest enterprise management to changes throughout the history is a very complex and dynamic issue to follow and understand. Nevertheless, at the same time such information may significantly assist the better understanding and following of forest enterprise management. Hence, this data may help other forest enterprises in showing them a way to further develop, handle and adapt to changes in the environment.

The analysis and review of the existing literature reveals that a lot of changes occurred throughout the history of the forest enterprise management in Macedonia. Regardless of their origin and nature, they all influenced and initiated many changes within the enterprises themselves. In order to survive, these forest enterprises needed to develop and adapt to the ongoing changes in the environment. Based on the obtained results from the research it may be said that all forest enterprises established in Macedonia have followed the changes in the ecological and economic environment. This is confirmed by the fact that changes in forests areas, forest legislation and management initiated and were followed by the modifications in the forest enterprise management.

Concerning the testing of the organizational learning theory for the purpose of this study, some conclusions may be drawn. It is known that the organizational learning theory explores the way and models on 
which organizations learn and adapt to changes in the environment in order to survive and be competitive on the market. Therefore, organizations need to be flexible and adapt to the changing environment. From the results obtained by this research it is evident that all forest enterprises in Macedonia have more or less been developing and adapting to changes of the environment. Starting with the first federal forest organization "FESUMA", established in 1945, which was replaced by the newly-formed administration on forest industrial companies after a few years. Later, with the decentralisation of federal administration and the introduction of the new economic system, the main forestry administration was transformed into the Federal Administration of Forestry and remained so until 1965 when the Secretariat of Forestry at the Executive Council of NRM was formed. In the middle of 1968, the Secretariat of Forestry transformed into the Secretariat of Agriculture and Forestry of NRM.

After the constitutional changes in 1974 and the adoption of the Law on Associated Labour, or popularly called the Workers' Constitution, in 1976, the economic entities formerly working as companies, organizations and institutions, etc., were organized as Organizations of Associated Labour (OUR), or the Basic Organizations of Associated Labour (OOUR), respectively. This organization merged into Working Organizations (RO), and those into Complex Organizations of Associated Labour (SOUR). At the end of 1980, some changes occured in the organization of economic entities, changes based on the constitutional amendments passed in 1988, when the Trade Law was adopted (The Official Gazette of the Socialist Federal Republic of Yugoslavia, No. 77/88) when the current law on associated labour was practically suspended. All this changes continued until 1997 when thirty independent forest organizations, responsible for the management of state-owned forest in Macedonia, conjoined into one large public enterprise, called "Macedonian forests". This enterprise is still operational, although with the change of the political, social and economical system of the country, as well as with changes of forest areas, legislation and management, some modifications occurred in the structure of the enterprise. That is an ongoing process in order for this organization to adapt and survive on the market.

As Segne emphasize in his discipline, in order to survive on the market of a big importance for the organization is to have: ability to interact to other components of the system, people who have ability to create personal visions, ability to change the image on mental models, shared vision and team learning. Because when people learn and become more familiar with the reality, they become much more secure and comfortable to predict, change and adapt to the future. Hence, all the above mentioned issues are presented in the results which are a clear confirmation of the validity of the organizational learning theory and the five discipline of Segne, as well as the importance of the adaptation and development of forest enterprise management over time.

\section{REFERENCES}

1. BERTELSEN L, NERMAN A 2001 Internal communication in organizations under change. Master's thesis, Lulea University of technology, p 63

2. CHURCH A H, MCMAHAN G C 1996 The Practice of Organization and Human Resource Development in the USA's Fastest Growing Firms. Leadership and Organization Development Journal 2: 17-33

3. HALL R H 1996 Organizations, Structures, Processes and Outcomes, 6th. Ed, Prentice Hall, Englewood Cliffs, New Jersey

4. HALLGRÍMSSON T 2008 Organizational change and change readiness: Employees' attitudes during times of proposed merger. Master thesis, University of Tromso, p 52

5. JACOBS M 2007 Personal mastery: The first discipline of learning organizations. Vermont Business Magazine, 360 Cadwell Rd. East Tretford

6. CYERT R M, MARCH J G 1963 Behavioural theory of the firm, Prentice-Hall Inc, New Jersey, USA
7. PALMER I, HARDY C 2000 Thinking about management: Implications of organizational debates for practice. Sage Publication Inc California, p 352

8. SENGE P M 1990 The Fifth Discipline: The Art and Practice of the Learning Organization. Prentice-Hall, USA

9. WALONICK D S 1993 Organizational theory and behavior. Available at: http://statpac.org/walonick/organizationaltheory.htm (Accessed: 21 November 2012)

10. ELO S, KYNGÄS H 2008 The qualitative content analysis process. J Adv Nurs 62 (1): 107-115

11. STOJANOVSKA M 2006 Working conditions and their influence on the number of employees in the forestry in Republic of Macedonia. University of Forestry, p 120

12. National strategy for sustainable development of forestry in Republic of Macedonia 2006

13. ADEYEMO D O 2005 Public Enterprises Reform in Nigeria: A Review, Kamla- Raj. J Soc Sci 10 (3): 223-231 
